Section 1

\title{
The LinkVan Project: Participatory Technology Design in Vancouver
}

\author{
SUZANNE SMYTHE \\ Simon Fraser University \\ DIONNE PELAN \\ University of British Columbia Learning Exchange \\ SHERRY BRESHEARS \\ Simon Fraser University
}

\begin{abstract}
This article tells the story of "LinkVan,” a project that explores approaches to participatory technology design to forge more equitable digital and social relations in the Downtown Eastside (DTES) community of Vancouver, British Columbia. LinkVan began as a project to create a literacy-friendly online service directory for low-income and homeless citizens. We trace the experiences and patterns of digital inequality that led to the formation of the project and describe the evolving approach to technology design oriented to "the direct involvement of people in the co-design of the technologies they use” (Simonsen \& Robertson, 2013 p. 2). We consider insights from 58 user experience interviews that suggest the precariousness of access, the centrality of digital literacy education in participatory technology design, and the potential of side-by-side 'conversations at the interface' (Attar, 2005; Barbatsis, Comacho, \& Jackson, 2004) to imagine new digital landscapes and new social relations.
\end{abstract}

Keywords

digital inequality, participatory technology design, homelessness, digital literacy, community services

\section{Introduction}

This article considers the entanglement of digital literacies and digital equity in a project called 'LinkVan,' a participatory technology initiative located in the Downtown Eastside (DTES) neighbourhood of Vancouver, British Columbia. As authors, we comprise a member of the LinkVan project team (Dionne) as well as researchers (Suzanne and Sherry) who studied LinkVan's efforts to develop a literacy-friendly online service directory. As we describe in what follows, our experience in the LinkVan project challenged the very premise of technology-oriented responses to service provisions, and has led us to more closely examine the pedagogies and practices of participatory technology design (Buchmüller, Joost, Bessing, \& Stein, 2011; Forlano \& Mathews, 2014; Simonsen \& Robertson, 2013). We begin by describing the digital landscape of the DTES, including the history, demographics, and social issues that shaped LinkVan's work. We then elaborate on concepts of digital inequalities and participatory technology design, by 
way of foregrounding the themes that arose as we engaged in community technology fora, close observations of digital learning in drop in public computing centres, and user experience interviews. We conclude with reflections on the limits and potential of online services for low income citizens, and the potential of participatory approaches to technology design to create more equitable social and digital relations.

\section{Vancouver's Downtown Eastside Digital Landscape}

The Downtown Eastside community, like all of Vancouver, resides on unceded Coast Salish Territories. Also known as Q'umq'umal'ay in the Musqueam language, the DTES encompasses the eastern portion of the downtown core and the residential neighbourhood of Strathcona. The DTES is often referred to as the "heart of the city" (Walling, 2011). It was the site of the first City Hall, and Vancouver's first library, the Carnegie, which is still housed in the thriving Carnegie Community Centre. Since the arrival of settlers in Vancouver in the 1850s, the community has been an ethnically diverse, working class neighbourhood, and the 'heart of the city' because it is known to be dynamic, community-oriented and resilient, home to artists, activists and social innovation (Lupick, 2017). While about 18,000 people call the DTES home (City of Vancouver, 2013), many experience homelessness or cycle in and out of temporary housing. This is perpetuated by insufficient incomes, rapidly rising rents, economic downturns in other parts of Canada, and the prevalence of untreated addictions, mental illness and trauma (Metro Vancouver, 2017).

It is unclear how many people experience homelessness in the DTES itself because people move throughout the city to find safe places to sleep. According to the 2017 homeless count in Metro Vancouver, 3,876 people in Vancouver were found to be sleeping outdoors, in tent cities or in shelters. Indigenous people comprised $35 \%$ of this group (Metro Vancouver, 2017). This over-representation of indigenous people among homeless or insecurely housed citizens flows from Canada's colonial history, manifest in the dispossession of indigenous peoples of their territories, including what is now the DTES as well as other parts of the city, the province, and Canada. These colonial relationswhich continue to be enforced through the 1867 Indian Act (Coulthard, 2014; McKenzie, Varcoe, Browne, \& Day, 2016) — are and have been expressed in projects of assimilation such as the residential school system, which has had a profound and lasting effect on residents of the DTES. Residential schools deployed immersive forms of colonial pedagogies (Hutchings, 2016) in an attempt to destroy indigenous relations with the land, and cultural and knowledge systems (Truth and Reconciliation Commission of Canada, 2015). In their engagements with literacy organizations and other community agencies, many indigenous residents of the DTES express their ongoing distrust of education, health, policing, and other government institutions (Sterritt, 2007; Truth and Reconciliation Commission of Canada, 2015).

Additionally, Chinese and Japanese families have lived in the DTES neighbourhood since migrant workers from these countries were recruited to work on the Canadian National Railway in the late $19^{\text {th }}$ century. Home to the city's collection of Single Room Occupancy (SRO) hotels and boasting more temperate weather than other parts of Canada, the DTES has historically attracted migrant and itinerant labour; however, it has never been able to adequately house its residents in the context of British Columbia's expensive real estate and weak social housing policies (Li, Moore, \& Smythe, 2017). In 
recent years, gentrification and restrictive income assistance and employment policies have exacerbated this problem (Downtown Eastside Literacy Roundtable, 2017). Over the course of our research between 2015 and 2017, rents rose sharply, but housing allowances for those on income assistance remained frozen at the 2002 rate of $\$ 350$ per month (Tweddle, Battle, \& Torjman, 2013). As one community member observed during our research: "We are getting squeezed into a smaller and smaller corner of this community" (Participant 23, October 23, 2016).

These very processes that contribute to income and housing inequalities also play out in patterns of digital access (Haight, Quan-Haase, \& Corbett, 2014). For example, in the interviews the LinkVan team conducted to understand patterns of digital access in the DTES (the methods of which we describe below), we found that precarious housing was connected to precarious digital access. Sixty-five percent, or 38 of the 58 interview respondents, said they relied on the public library or public Wi-Fi in community centres or coffee shops for their internet access. The two public libraries serving the community are brimming each day with people needing both access to the internet and further support to send emails, connect with family and friends, complete online forms, and so on. Though the younger participants in our study (aged 18 to 30)—most of whom reported as having some college education-were more confident users of technology, this group was also more likely to be homeless or reliant upon shelters, and least likely to have reliable access to the internet.

In spite of its difficulties, the DTES is also known as a resilient and tight-knit community that resists processes of gentrification and advocates for the rights of its most vulnerable through memorial marches, protests against local government decisions, and inter-agency collaborations and collective action (Walling, 2017). Indeed, it was one such collective action that gave rise to the LinkVan project.

Digital Inequality, Digital Literacy, and Participatory Technology Design

Digital inequality refers to the unequal distribution of digital, social, and educational resources that are required for participation in a digital society (Robinson, Cotten, Ono, Quan-Haase, Mesch, et al, 2015). These authors argue that "first level” digital disparities, such as access to the Internet and working devices, continue to proliferate in North America alongside "second level” digital inequalities such as consistent access to appropriate and timely digital literacy education, secure internet connections, and safe places in which to use these technologies. They observe that digital inequalities are entangled with and reinforce "offline axes of inequality" (Robinson et al, 2015, p. 570) across income, age, gender, race, and geographic location disparities, so that "[o]ne cannot understand the social landscape of the twenty-first century without coming to grips with digital inequalities” (Robinson et al, 2015, p. 571).

A linking concept between digital literacy and digital inequality is that of usability. Usability refers to engagement and experience with the "content, systems, and environment” of technology use (O’Brien, 2016, p. 22). If a system is not usable (for example, if it requires a printer, power source, or a particular browser that users do not have), there can be no engagement; user experiences can be negative, foreclosing the important experience of pleasure that promotes digital literacy fluency (O’Brien, 2016; Reder, 2012; van Dijk, 2006). Here, the digital ecosystem, or material contexts in which technologies are used, matter for engagement and access, in that "engagement with place 
can be more salient than engagement with a device” when learning new concepts (O'Brien, 2016, p. 3-4). This multifaceted concept of usability attends to the qualities of the digital ecosystem, proceeding from the view that all users, no matter how they are situated, have a right to pleasurable experiences with technology (Buchmüller et al, 2011, p. 756). This broadens definitions of digital literacy-beyond that which is an effect of individual skills and cognition - to include the social and political processes through which technologies are created (Selwyn, 2012). Who designs technologies, and for whom are they produced? How do these design relations affect literacy experiences and digital access?

Most often technologies are designed for people, not with them. Moser (2009) calls this an "executive approach" (p. 714), in which technologies are designed by software engineers or in government offices for a homogeneous market of consumers. This approach results in technologies that privilege model users (Woolgar, 1991) who enjoy ubiquitous access to the internet, operate multiple devices, and accrue the benefits to digital fluency of regular opportunities for practice. An executive approach to technology design can therefore perpetuate digital inequality, because the resulting technologies may not be useable or meaningful for those who are not model users.

Buchmüller et al (2011) further argue that the design of technologies is a social process rather than a technical one. Participatory design processes (or co-design, as the literature uses the terms interchangeably) attend to the quality of people's experiences at the computer interface (i.e., what people actually do) and locate these experiences in the broader ecosystems and social contexts for digital in/equalities; there is an expressed interest in how marginalized users interact with technologies, rather than assuming they do not, or cannot. Forlano and Mathews (2014) found that including low-income citizens in the development of an online community information directory-one with similar aims to that of LinkVan - led not only to a more intuitive design but also to capacity building, through which supported community members could envision desired, more equal futures.

\section{LinkVan's Process: Improvisation and Experimentation}

It was the desire to build community capacity for digital technology use, and to envision more equal digital and social futures, that led to the creation of LinkVan. LinkVan is a project of the Downtown Eastside Literacy Roundtable, an interagency collaboration among literacy and education organizations in the DTES that meets monthly to share information, support access to their programs, and respond to community literacy needs. Its members include representatives from community colleges and universities that offer adult literacy and adult basic education programs as well as local libraries, employment training groups, literacy drop-in programs, women's centres, and indigenous language circles. In 2015, these members expressed concern over the rapid shift to online government services underway in the community and the effect this was having on people's access to services-particularly for those who are homeless or precariously housed (Association of Community Organizations for Reform Now [ACORN], 2016; British Columbia Public Interest Advocacy Centre [BCPIAC], 2015). Roundtable members were also concerned about the capacity of their volunteer-run agencies to meet this growing demand for digital access and digital literacy skills. They asked the roundtable coordinator, William Booth, to take the lead in organizing a community technology forum to discuss these issues and develop possible actions. This led to the birth of LinkVan. In the following sections, we describe the subsequent evolution of the project-first in community 
technology fora, then in user experience interviews, observations of technologies-in-use in drop-in digital literacy classes, and in outreach and advocacy activities.

\section{The First Community Technology Forum}

At the first community technology forum, hosted by the University of British Columbia (UBC) Learning Exchange and the Downtown Eastside Literacy Roundtable in the fall of 2015, 60 community members and representatives of local agencies discussed the digital disparities in the community. Just as services upon which residents relied were moving online, the internet was becoming more expensive and out of reach for low-income citizens. Adult education programs that once offered digital education and internet access had closed due to provincial and federal cuts (Smythe, 2015; Smythe \& Butterwick, 2014). Some online service directories were on offer, but they were difficult for people to navigate, information was hard to read, and government forms in particular required access to Adobe Reader DC software, a telephone, and a printer (BCPIAC, 2015). ${ }^{1}$ At the crux of the problem was a prevailing perception among government agencies and policy makers that the digital divide had been eradicated with the introduction of Wi-Fi hot spots and internet in libraries (Moll, 2012), and that homeless and low-income residents either did not experience significant barriers to accessing online services or that digital access was the least of their worries. These discussions resonated with reports of digital inequalities among low-income and homeless citizens in other jurisdictions. In their study of public computing in a homeless shelter for mothers in the United States, Le Dantec et al (2011) observed:

Someone who is homeless may not have extensive access to digital technologies but is nonetheless deeply affected by the pervasiveness of such technologies in everyday life. In everything from maintaining social connections to friends and family, to online registration and verification for social services, to finding and applying for employment and housing, the presence and necessity of interacting with technology has real consequences - and opportunity — for the urban homeless. (p. 1)

If people accepted the view that digital technologies were pervasive in the lives of DTES community members, then ensuring their usability would become a matter of urgency.

\section{Making the LinkVan Directory}

During discussions about next steps and actions at the first community technology forum, participants identified the urgent need to create an open-source, literacy-friendly directory of services that responded to the particular needs of the DTES community. The

\footnotetext{
1 Problems of access to government services, including income assistance, disability benefits, and employment insurance, are well documented in the B.C. Public Interest and Advocacy Centre's 2015 report to the B.C. ombudsperson, Access denied: Shut out of BC's welfare system http://bcpiac.com/wpcontent/uploads/2015/09/BCPIAC-Ombuds-Complaint_Final_May-12-2015.pdf, and in the 2016 report by the anti-poverty group, Association of Community Organizations for Reform Now (ACORN), Internet for all: Internet use and accessibility for low-income Canadians, http://www.acorncanada.org/resource/internetall.
} 
rationale was that such a resource might afford more privacy and discretion for those looking for services. This was important for newcomers to the community, who may be in crisis but who do not want to tell their story to one community agency after another until they are directed to the appropriate service. Another rationale for a literacy-friendly directory was that other online service directories on offer were difficult to navigate for people with reading difficulties and were not enabled to provide local information, making them unreliable. For example, in one directory, a map that was linked to the UBC Learning Exchange (UBCLE) directed people to the UBC campus-15 kilometres away-rather than to the UBCLE storefront in the core of the DTES.

Kevin Tanyag, a UBC computer engineering student who volunteered at the UBCLE, was asked to find or develop a model for a more intuitive platform. He identified Link-SF, a tool created by San Francisco's Zen Desk (2016) and described as "San Francisco's first mobile-optimized website that connects homeless and low-income residents with critical and life-saving resources nearby” (Link-SF, 2018, para 1). With support from a small innovation grant, Kevin began working on a Link-Vancouver version, tailored to the Vancouver context. A LinkVan project team, formed to guide and advise this process, included representatives of the Downtown Eastside Literacy Roundtable, the UBC Learning Exchange, volunteer computer science and software engineers, and community members, called community ambassadors, who were delegated by community groups to inform the project from the perspective of people without regular access to the internet, devices, or digital education.

\section{Designing the LinkVan with Community Service Providers}

The participation of service providers in the design of LinkVan was crucial, because the accuracy and usefulness of information was dependent upon the information agencies shared. In a second forum in early 2016, community service providers were asked to envision how the LinkVan directory could be used, and by whom. They imagined potential outcomes and uses for the directory that led not only to better access to services, but also to more equitable distribution of digital resources skills. The participants identified both community service agencies and community members who use their services as the directory's principal audiences. They brainstormed categories of services to feature in the directory, and noted the importance of an offline directions and map feature so that people with phones could follow directions without needing cell phone data. The limited availability of free, public Wi-Fi in Vancouver streets and parks in 2016 made this a vital usability feature. $^{2}$ These suggestions were included in the first iteration of the LinkVan directory (see Figure 1).

\footnotetext{
${ }^{2}$ The City of Vancouver has since partnered with Shaw Communications to increase free Wi-Fi access throughout the city (City of Vancouver, 2018). However, these are still spotty and many are located in private businesses where homeless citizens do not feel welcome. See Stanley Q. Woodvine's (2018) audit of free Wi-Fi in Vancouver from the perspective of a homeless citizen.
} 


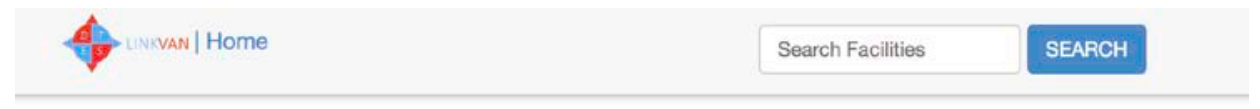

What service are you looking for?

\begin{tabular}{|c|c|}
\hline 蒠 Shelter & $>$ \\
\hline$\Psi$ Food & $>$ \\
\hline Uj Medical & $>$ \\
\hline Hygiene & $>$ \\
\hline Technology & $>$ \\
\hline ST Legal & $>$ \\
\hline Learning & $>$ \\
\hline A Crisis Lines & $>$ \\
\hline
\end{tabular}

Figure 1. The first iteration of LinkVan, June 2016.

\section{Usability Testing: Folding Local Knowledge into Design}

With this first iteration of LinkVan ready, and with the benefit of a SSHRC small grant, community ambassadors Wilson Liang and Diane Campbell worked with Sherry and Suzanne to gage its usability among community members. We were interested in learning how people engaged with the directory, but also how they experienced the digital ecosystem in which it might be used; for example, the extent to which people experienced safe and reliable access to devices, the internet, and learning opportunities (see Appendix A for the interview protocol). We took a laptop with screen capture software into a women's centre, a shelter, and two community centres in the downtown area, interviewing 58 people over 6 months. Among these respondents, 55\% identified as women and $45 \%$ as men; $82 \%$ were from racialized groups, respondents were between the ages of 23 and 80 , with most between 28 and 60; and 54\% had lived in the community for over 10 years, with $15 \%$ between 5 and 10 years, and 30\% for less than five years, with most of these being quite recent arrivals. These figures attest to dynamics of housing instability in the community; even long timers in the community experience homelessness and insecure housing. Thirty-two percent (19) of respondents were homeless at the time of the interview, which included relying upon shelters, sleeping outdoors, and/or couch surfing. Two percent, or 6 respondents, were living in transitional housing, and 66\% of the participants (36) lived in local SROs or senior residents' or subsidized housing. Awareness of these diverse housing experiences enriched our understanding of digital access and the usability of LinkVan; however, we did not approach people for interviews based on their housing status, and we do not claim that these housing experiences are representative of the situation in the DTES. Regardless of living arrangements or time in the community, $80 \%$ of the participants had no home internet or cell data, because these were unaffordable or unavailable in SRO hotels or residences. 
During the interviews, we sat next to participants with a laptop facing us on a table. We first asked people to use the directory to find various services, and as they did so, to share with us their experiences of the search functions and the relevance of the information they found. We soon noticed that asking people to use a new or unfamiliar device to find a service with which they may have little knowledge or experience is not an authentic literacy practice (Campbell, 2003; Lesgold \& Welch-Ross, 2012). Principles of adult literacy education have taught us that "purposeful and meaningful learning builds upon and expands on learner's prior knowledge” (Duckworth \& Brzeski, 2015, p. 2). The same is true for digital texts and app and website navigation. When people make their way to a website or app, it is because they are already looking for information, and so they are more able to find and evaluate this information in the context of their background knowledge and their goals for searching. For this reason, we soon dropped the testing component and adopted an approach oriented to "conversations at the interface” (Attar, 2005; Barbatsis, Comacho, \& Jackson, 2004, p. 43)—collaborative explorations of the search functions, literacy features, and information generated by the site. For example, rather than waiting to see if people could correctly locate the service we asked them to search for, we encouraged people to freely explore the site-clicking on different features, moving the cursor here and there, viewing and commenting on icons such as those for medical services, showers, or those that denote women-only services. When necessary, we guided people to use the mouse and track pad, or type into a search field. If a participant seemed lost, we would prompt, "can you find the nearest shelter?” or "what makes it hard to find women's only shelters?” Often participants offered commentary when they landed on a familiar place. "I would never go there, or there, or there," mused one participant as she scrolled the mouse over the names of shelters (Participant 14, June 9, 2016). "I have a place there tonight," commented another (Participant 18, June 9, 2016).

After Wilson, Diane, Sherry, and Suzanne shared summaries of participant responses in LinkVan team meetings, changes to the app were rolled into the next iterations. For example, the "home" icon was adjusted to be clearer to find in the second iteration. Several community respondents told us that the icon for medical services (see Figure 1) triggered an uncomfortable response for them, having had difficult histories and interactions with health care institutions and providers. By the third iteration, a new iconthat of a stethoscope-enjoyed a more favourable reception, and Learning was added as another service category. However, not all suggestions from participants were adopted. The software developers wanted to limit frequent changes to the site that could diminish familiarity and user engagement. Some popular suggestions, such as creating a live feature to book shelter beds in real time, could not be implemented because LinkVan, a volunteer run and supported project, did not have the capacity to maintain this information, and because some service providers were reluctant to provide it. We return to this issue in the discussion, as we consider the constraints of participatory design processes. 


\begin{tabular}{|c|c|}
\hline 트 Shelter & $>$ \\
\hline "W Food & $>$ \\
\hline 若 Medical & $>$ \\
\hline ? Hygiene & $>$ \\
\hline$\square$ Technology & $>$ \\
\hline QD Advocacy & $>$ \\
\hline A Crisis Lines & $>$ \\
\hline
\end{tabular}

Figure 2. The third iteration of the LinkVan homepage.

\section{Digital Literacy Education Outreach}

During our conversations with community members, it became clear that there was a strong demand for digital literacy education in the community. We also observed a wide range of fluency and proficiency with devices, from the younger, college-educated homeless youth who deftly negotiated the LinkVan site to those who were unfamiliar with using keyboards and a mouse or tracker. The Vancouver Public Library has a mandate from the City of Vancouver to provide digital literacy education to Vancouverites-usually in the form of workshops and drop-in tech support, for which there is high demand. Yet it is difficult for librarians to meet these complex needs on their own (Jaeger \& Bertot, 2011), and given the history of residential schooling noted above as well as reasons of trauma and mental health, many people in the community are not comfortable to learn in unfamiliar or anonymous group settings. To become more digitally fluent, people need time to practice new skills in familiar settings, with frontline workers and educators with whom they have trusted relationships. Many respondents also expressed that the day-to-day work of survival made it more difficult for them to learn in scheduled or traditional ways.

The LinkVan project responded to these dynamics by creating pop-up tech cafés in shelters, drop-in centres, and other settings where people already gathered and felt comfortable. This affirms the findings of user-engagement studies cited above- that place matters in technology engagement. Locating tech cafés in community settings also built the capacity of stretched agencies to embed digital access and literacy into their community work. The format was simple: A few times a week in different community settings, the LinkVan team set up a table with a sign that read, "need help with digital technology?" and included images of a cellphone, laptop, tablet, and logos of well-known social media and web sites. A Vancouver public librarian brought along a mobile hotspot and, with community ambassadors Wilson and Diane, as well as with Dionne, William, and others, 
helped those who visited the table. The team focused on relationship building and timely, one-to-one digital literacy mentorship based on what people wanted to learn, stretching this into explorations of new digital terrains and skills. It was in these tech cafés that team members noticed persistent digital literacy trouble spots (such as passwords, accounts, and government forms) and gained further insight into how people used and responded to the LinkVan interface.

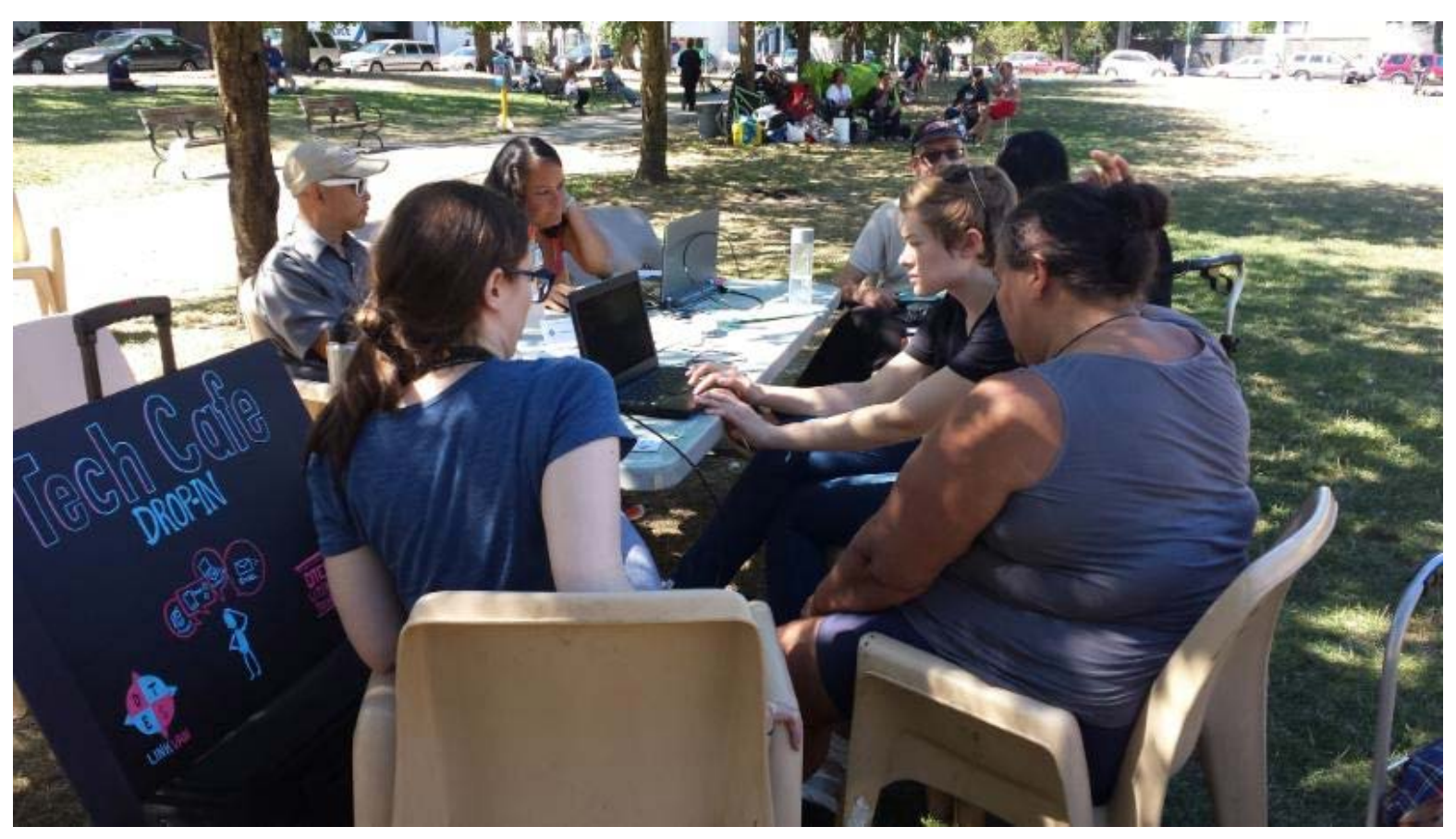

Figure 3. Tech café drop-in at Oppenheimer Park, Downtown Vancouver.

In the following section, we elaborate on the findings of these "conversations at the interface" (Barbatsis, Comacho, \& Jackson, 2004, p. 43) and observations of technologiesin-use in the tech cafés. It was within these interactions that more complex configurations of digital equity arose, challenging the assumptions and goals of the LinkVan project and provoking interesting new problems to pursue.

\section{Learning from the LinkVan Project}

\section{Improvisations and Workarounds Enact More Equitable Digital Landscapes}

Paying attention to how marginalized technology users negotiate digital landscapes offers insights into how these landscapes might be transformed. As noted above, prevailing digital policy in Canada conceives of low-income and homeless citizens as those who struggle with digital literacy and who may be unable or unwilling to use new technologies. But all the participants in our study said they use technologies daily. Although our study may have attracted people who already had an interest in technologies, the popularity of the tech café drop-ins and the high demand for digital literacy in the public libraries suggest that low-income and homeless citizens, just like their more affluent fellow citizens, desire and are compelled to use technologies - only they must work much harder to do so. Our conversations with community members attuned us to how people improvise and work 
around barriers to access. One interview participant, Nicole, declared that internet was free in the community. "It's free?” Suzanne was surprised but Nicole continued: "You just have to stand outside for a long time. I can see people standing there all night using the internet. [...] A lot of places leave it on." When Nicole had a phone, she too would tap into these available connections, and is familiar with several "secret" outdoor electrical outlets within the area (Participant 18, June 9, 2016). We also learned that people share skills, devices, and information with others - in ways that disrupt the hyper-individualized design of personalized devices oriented to consumer markets (Elliot \& Urry, 2010; Gubrium, Harper, \& Otañez, 2015).

\section{Digital Inequalities: Scarcity in a Sea of Plenty}

Thirty-two percent, or 19 of the interview participants, 9 of whom were homeless at the time of the interview, said they had a mobile phone-although they often had older operating systems, without cell data. Phones provide invaluable access to Whatsapp, Facebook Messenger, and other internet-enabled messaging and voice calling platforms. Participants who were sleeping outside or in shelters said that one of their greatest fears was having their phone stolen while they slept, and several said their phone had been recently lost or stolen-a devastating experience because they also then lost contact numbers of family, friends and other connections. "When people are ready to make a change in their life, to ask for help, the first thing they need is a cell phone," noted one participant (Participant 33, November 3, 2016). Going without a phone when homeless can make one feel especially lonely and vulnerable. One young woman told us that she puts her laptop and cell phone in lock up at a local community agency at night. "So, after 8pm, I have no technology on me... I don't want them to get stolen when I am sleeping out. It's like I am off the grid” (Participant 12, June 8, 2016). For these reasons, several people who had experienced having their phone stolen planned to use their social assistance cheque to replace it, even if this meant they would have no money left for food. In this way, access to cell phones are not a luxury but a necessity for social and digital inclusion.

\section{Digital Literacy and the Digital Landscape}

In line with research cited above on the important role of place in technology usability (O'Brien, 2016), the aesthetic and material conditions of public computing spaces such as shelters, residence lobbies, and drop-in centres seemed important to the quality of people's digital learning experiences. Community members reported that they feel anxious and pressured to work faster when they use computers in public spaces because of the high demand for very few computers. Overstretched staff and volunteers may be unable to help those who have difficulties using the computers and many reported that computers in these drop-in settings are not working properly or have old operating systems. Women respondents said some public computing spaces were male-dominated and they felt unsafe there: "What we need are women-only computer labs" (Participant 13, June 8, 2016). Some respondents expressed concern with a lack of privacy in public computing settings, as when people forget to log out of their email or Facebook page, or private information is inadvertently shared in an open room when someone is getting help with a government form.

By offering digital literacy learning opportunities to visitors of the tech cafés, LinkVan strived to create a digital landscape in which people saw themselves as included 
members of a digital society. We noticed that these outreach activities formed a bridge to more formal learning opportunities. For example, participants made personal connections with people running the tech cafés and began to visit their literacy programs. Jane ${ }^{3}$ is one such person. She was a regular visitor to the tech cafés in the local park and lived nearby at a local women's shelter. She met Dionne at one of these tech cafés and began to visit her at the UBC Learning Exchange's drop-in computer lab. One day, a volunteer tutor was helping Jane to learn how to export photographs from her cell phone. Jane was anxious; her daughter was missing and the Vancouver Police Department required a current photo. While Marie, one of the volunteer tutors, was showing her how to download and share pictures on Facebook, Jane's daughter contacted her for the first time in over a month and Jane was able to respond to her daughter in that moment. Spurred by this breakthrough, she became much more proficient at using her phone and has since reconnected with her sister, who now also attends the café regularly. This suggests, once again, the entangled social, temporal, and spatial relations that surround technology use.

\section{Service Directories Are Not Actual Services}

In the multimodal flow of scrolling, scanning, and clicking during the interviews, we were also introduced to the limits of services, and of technologies, to address unequal social and political systems. An insightful interview participant scanned LinkVan's menu of services and asked: "Where is your category for housing? We don't need more shelters, we need housing” (Participant 19, June 9, 2016). As another man, following our prompt, scrolled to find a shelter, he hovered over one and explained, "[This] is a low barrier shelter, which means there are people there who, you know, have a lot of issues. I can't relax there, I don't feel safe, so I sleep on a chair in the entrance area. I wish they had high barrier shelters or no shelters at all” (Participant 45, February 28, 2017). Another was disdainful of the LinkVan initiative: "Why have a directory of services when there are no services?" (Participant 43, February 28, 2017). Still others emphasized that the LinkVan directory would only be useful if the information it provided was accurate and reliable: "It is better to have no information than inaccurate information" (Participant 46, February 28, 2017). This aligns with observations from studies of user experience and usability cited above (Le Dantec \& DiSalvo, 2013; O’Brien, 2016)—namely, that people assess the validity and trustworthiness of the content of online information against their local knowledge and experience. When content conflicts with these, the integrity and usability of the site erodes. Moreover, when services are listed in a directory, their presence may offer the impression that such services exist and are plentiful, when this is may not be so; shelters turn away people on a regular basis, there are few detox programs in the community or the city, and few supports are in place for people experiencing mental health difficulties.

\section{Discussion and Conclusions}

As the LinkVan project continues to evolve, so too does the thinking and problemsolving oriented to the design and use of LinkVan within the DTES digital ecosystem. The improvisations and workarounds in which citizens engage suggest actions that might disrupt digital inequalities, such as widening public access to affordable internet and WiFi, day and night; scaling up existing initiatives to distribute refurbished cell phones and laptops (for example, in projects run by Free Geek and Computers for Schools); and

\footnotetext{
${ }^{3}$ Nicole and Jane are pseudonyms
} 
offering more timely and appropriate digital literacy education. Yet the LinkVan project not only generates solutions; it also raises provocative and productive new problems, as well as "wicked" and entangled issues that get at the heart of colonialism, racism, neoliberal housing policies (Hutchings, 2016), and the commodification of digital landscapes. None of these have easy solutions, but if we "stay with the troubles" (Haraway, 2016, p. 1) that inevitably erupt in participatory processes such as LinkVan, we may, as Jen Ross (2017) proposes, "produce valuable insights and contribute to a flourishing ecosystem of knowledge practices” (p. 215). In other words, rather than as a rush to solutions, we might think of participatory design as "inventive problem-making" (Michael, 2012, p. 536) — an engagement with imaginative resources, such as those demonstrated by community members in this study, "aimed at envisioning or crafting futures or conditions which may not yet currently exist, to provoke new ways of thinking and to bring particular ideas or issues into focus” (Ross, 2017, p. 215). Among the new ways of thinking and ideas that proliferated in the LinkVan project, we signal three that called out to us as potentially productive to track as the project continues to unfold.

The first is the problem of scarcity. Despite the best efforts of community service agencies, there is a scarcity of cell phones and affordable internet, homes and healthcare, digital literacy education and employment for low-income and homeless citizens in the DTES digital landscape. This scarcity, amidst the abundance of resources mere blocks away in any direction - or even inside some of the new luxury condos or swanky coffee shops sprouting alongside shelters and tent cities in the neighbourhood-drives home the extent of visible, palpable, in-your-face digital and social inequalities. What if digital inequalities were not a problem of scarce resources, but rather a more "wicked" problem of powerful discourses that normalize scarcity as a necessity, lest people get access to things they 'don't deserve'? To counter these discourses, projects of digital inclusion might relinquish a so-called if only approach to technology (Kim, 2014); that is, if only people had higher digital literacy skills, poverty would disappear, or if only internet connections were everywhere, people would be able to find a place to live. Even the most intuitive and functional service directory cannot provide access to actual resources if society has decided people don't really deserve them.

This highlights another productive tension in the LinkVan project. While the project addresses the need for literacy-friendly and accessible information about services and resources, its digital inclusion mandate is also to create a more equitable social and digital landscape so that people need not rely upon scarce services to live their everyday lives. Thus, in addition to being a pragmatic response to an ongoing crisis, LinkVan may also be a force in undoing that crisis.

The desires of different users of LinkVan open up another interesting problem of power relations in technology co-design. Participants in our study wanted accurate, justin-time information about services, as well as the capacity to claim them in real-time (for example, a shelter bed or a shower). But many community service providers are reluctant to provide this option; they want the discretion to screen and triage access to their services, and to maintain opportunities for human interaction that are central to trust building. This creates a tension between the potential for anonymity in online services, and the deeply relational work of community outreach, opening up important questions about the role of humans in human services that are moving online. Perhaps the value of participatory design 
is not only to enact desired futures — or even meet needs—but to create new relationships and possibilities for grappling with "wicked" problems.

Ross (2017) calls upon digital literacy educators and designers to embrace the "not yet-ness" (p. 214), or imperfect and unfinished nature of technologies, and to maintain a creatively critical stance towards digital futures for education-one that involves "navigating multiple and often competing visions without succumbing to cynicism, a narrowing of perspective" (Ross, 2017, p. 218). With this in mind, next steps for LinkVan might be to reach beyond the technological; to "experiment with possible futures" (Gunn, Otto, \& Smith, 2013, p. 18) — such as one in which homes replace shelters, or abundance supplants scarcity—in thinking about how resources essential for living are shared.

\section{Acknowledgments}

This study was supported by a SSHRC Small Grant, "Participatory technology design and digital inclusion" GT20258, Simon Fraser University. The authors would like to thank the community agencies who hosted the interviews, the LinkVan project team and in particular William Booth, Diane Campbell and Wilson Liang for their invaluable contributions to the interviews and to the LinkVan project.

\section{References}

Association of Community Organizations for Reform Now. (January, 2016). Internet for all: Internet use and accessibility for low-income Canadians. Retrieved from https://www.acorncanada.org/internet-all-internet-use-and-accessibility-lowincome-canadians

Attar, D. (2005). Dismay and disappointment: Perspectives of inexperienced adult learners on becoming webpage readers. International Journal of Educational Research, 43(7-8), 495-508.

Barbatsis, G., Camacho, M., \& Jackson, L. (2004). Does it speak to me? Visual aesthetics and the digital divide. Visual Studies, 19(1), 36-51.

British Columbia Public Information Advocacy Centre. (2015). Shut out of BC's Welfare System: Complaint to the Ombudsperson of British Columbia regarding service delivery at the Ministry of Social Development and Social Innovation. Retrieved from http://bcpiac.com/wp-content/uploads/2015/09/BCPIAC-OmbudsComplaint_Final_May-12-2015.pdf

Buchmüller, S., Joost, G., Bessing, N., \& Stein, S. (2011). Bridging the gender and generation gap by ICT applying a participatory design process. Personal \& Ubiquitous Computing, 15(7), 743-758.

Campbell, P. (2003). Teaching reading to adults: A holistic approach. Grassroots Press: Edmonton, AB.

City of Vancouver (2013). Downtown eastside local area profile. Retrieved from http://vancouver.ca/files/cov/profile-dtes-local-area-2013.pdf

City of Vancouver (2018). City partners with Shaw to expand public access to free wifi. Retrieved from http://vancouver.ca/news-calendar/city-partners-with-shaw-toexpand-publics-access-to-free-wi-fi.aspx

Coulthard, G. S. (2014). Red skins, white masks: Rejecting the colonial politics of recognition. St. Paul, MN: University of Minnesota Press. 
Downtown Eastside Literacy Roundtable (2017). Strengthening literacy in the Downtown Eastside. Retrieved from https://dteslit.files.wordpress.com/2016/08/dtes-adultliteracy-roundtable-report-and-goals-2015-dra015.pdf

Duckworth, V. \& Brzeski, A. (2015). Literacy, learning and identity: Challenging the neo-liberal agenda through literacies, everyday practices and empowerment. Research in Post-Compulsory Education, 20(1), 1-16.

Elliot, A. \& Urry, J. (2010). Mobile lives. London, UK: Routledge.

Forlano, L., \& Mathew, A. (2014). From design fiction to design friction: Speculative and participatory design of values-embedded urban technology. Journal of Urban Technology, 21(4), 7-24.

Gubrium, A., Harper, K., \& Otañez, M. (Eds). (2015). Participatory visual and digital research in action. London: Routledge.

Gunn, W., Otto, T. \& Smith, R.C. (2013). Design anthropology: Theory and practice. London, UK: Bloomsbury.

Haight, M., Quan-Haase, A., \& Corbett, B. A. (2014). Revisiting the digital divide in Canada: The impact of demographic factors on access to the internet, level of online activity, and social networking site usage. Information, Communication \& Society, 17(4), 503-519. doi:10.1080/136

Haraway, D. (2016). Staying with the trouble: Making kin in the chtulucene. London, UK: Duke University Press.

Hutchings, K. (2016). Cultural genocide and the First Nations of Upper Canada: Some romantic-era roots of Canada's residential school system. European Romantic Review, 27(3), 301-308.

Jaeger. P. T \& Bertot, J.C. (2011). Responsibility rolls down: Public libraries and the social and policy obligations of ensuring access to e-government and government information. Public Library Quarterly, 30(2), 91-116.

Kim, M. (2014). Designs on mobility: Perceptions of mobile phones among the homeless. Retrieved from http://www.cogsci.ucsd.edu/media/uploads/undergrad/2014_thesis_melody_kim_ designsonmobility.pdf.

Le Dantec, C. \& DiSalvo, C. (2013). Infrastructuring and the formation of publics in participatory design. Social Studies of Science, 43(2), 241-264.

Le Dantec, C., Farrell, R., Christensen, J., Bailey, M., Ellis, J., Kellogg, W., \& Edwards, W. (2011). Publics in practice: Ubiquitous computing at a shelter for homeless mothers. In Proceedings of the SIGCHI Conference on Human Factors in Computing Systems (pp. 1687-1696). Available from https://dl.acm.org/citation.cfm?id=1979189

Lesgold, A. M. \& Welch-Ross, M. K. (2012). National Research Council. Improving adult literacy instruction: Options for practice and research. Washington, D.C.: National Academies Press.

Li, J., Moore, D. \& Smythe, S. (2017). Voices from the heart: Understanding a community-engaged festival in Vancouver's downtown eastside. Journal of Contemporary Ethnography, 1-25. Advance online publication.

LinkSF (2018). About LinkSF. Retrieved from https://link-sf.com/about

McKenzie, H. A., Varcoe, C., Browne, A. J., \& Day, L. (2016). Disrupting the continuities among residential schools, the sixties scoop, and child welfare: an 
analysis of colonial and neocolonial discourses. International Indigenous Policy Journal, 7(2), 1-16.

Metro Vancouver (2017). 2017 Homeless count in Metro Vancouver final report.

Retrieved from http://www.metrovancouver.org/services/regional-

planning/homelessness/HomelessnessPublications/2017MetroVancouverHomeles sCount.pdf

Michael, M. (2012). “What are we busy doing?” Engaging the idiot. Science, Technology, \& Human Values, 37(5), 528-554.

Moll, M. (2012). A brief history of the community access program: From community economic development to social cohesion to digital divide. In A. Clement, M. Gurstein, G. Longford, M. Moll, \& L. R. Shade (Eds.), Connecting Canadians: Investigations in community informatics (pp. 485-490). Edmonton, AB: University of Athabasca Press.

Moser, M. A. (2009). Text "superpowers:" A study of computers in homeless shelters. Science, Technology, \& Human Values, 34(6), 705-740.

O’Brien, H. (2016). Theoretical perspectives on user engagement. In O’Brien, H. \& Cairns, P. (Eds), Why engagement matters: Cross-disciplinary perspectives of user engagement in digital media (pp. 1-26). Cham, Switzerland: Springer.

Reder, S. (2012). The longitudinal study of adult learning: Challenging assumptions. (Research brief). Retrieved from http://www.centreforliteracy.qc.ca/sites/default/files/CFLRsrchBrief_Chllngng_A ssmptns.pdf

Robinson, L., Cotten, S., Ono, H., Quan-Haase, A., Mesch, G., Chen, W., Stern, M. (2015). Digital inequalities and why they matter. Information, Communication \& Society, 18(5), 569-582.

Ross, J. (2017). Speculative method in digital education research. Learning, Media and Technology, 42(2), 214-229. doi: 10.1080/17439884.2016.1160927

Selwyn, N. (2012). Ten suggestions for improving academic research in education and technology. Learning, Media \& Technology, 37(3), 213-219.

Simonsen, J., \& Robertson, T. (2013). Routledge international handbook of participatory design. New York, NY: Routledge.

Smythe, S. (2015). Ten years of adult literacy policy and practice in Canada. In B. Nteliogiu \& J. Rowsell (Eds.), Special Issue: A landscape view of literacy and language issues in Canada. Language and Literacy: A Canadian e-Journal, 17(2), $4-21$.

Smythe, S., \& Butterwick, S. (2014). New adult education fees will harm BC jobs plan. Retrieved from http://theprovince.com/opinion/suzanne-smythe-and-shaunabutterwick-new-adult-education-fees-will-harm-b-c-jobs-plan

Sterritt, A. (2007). Racialization of poverty: Indigenous women, the Indian Act and systemic oppression. Reasons for resistance. Vancouver, BC: Vancouver Status of Women. Retrieved from:

http://vsw.ca/Indigenous\%20Women_DEC2007FINAL.pdf

Truth and Reconciliation Commission of Canada (2015). Honouring the truth:

Reconciling for the future. Summary of the Final Report of the Truth and

Reconciliation Commission of Canada. Retrieved from 
http://www.trc.ca/websites/trcinstitution/File/2015/Findings/Exec_Summary_201 5_05_31_web_0.pdf

Tweddle, A. Battle, L. \& Torjman, K. (December, 2013). Welfare in Canada, 2012. Toronto, ON: Caledon Institute of Social P olicy. Retrieved from https://www.cwpcsp.ca/resources/sites/default/files/resources/Welfare_in_Canada_2012.pdf

van Dijk, J. A. G. M. (2006). Digital divide research, achievements, and shortcomings. Poetics, 34(4), 221-235.

Walling, S. (2017). DTES history: Heart and home. Vancouver, BC: The Downtown Eastside Heart of the City Festival. Retrieved from http://www.heartofthecityfestival.com/dtes-history/heart-and-home/

Woodvine, S. Q. (January, 2018). Homeless in Vancouver: Nearly two-thirds of "free" city Wi-Fi in Fairview isn't freely available. Retrieved from https://www.straight.com/life/1022156/homeless-vancouver-nearly-two-thirdsfree-city-wi-fi-fairview-isnt-freely-available

Woolgar, S. (1991). Configuring the user: The case of use-ability trials. In J. Law (Ed.), A sociology of monsters: Essays on power, technology and domination (pp. 87102). London, UK: Routledge.

ZenDesk. (2016). About us. Retrieved from https://www.zendesk.com/about/ 